\title{
Oropharyngeal (p16-Negative) Cancer pTis TNM Finding v8
}

National Cancer Institute

\section{Source}

National Cancer Institute. Oropharyngeal (p16-Negative) Cancer pT is TNM Finding v8. NCI Thesaurus. Code C132917.

Oropharyngeal (p16-negative) cancer with a finding of carcinoma in situ. (from AJCC 8th Ed.) 